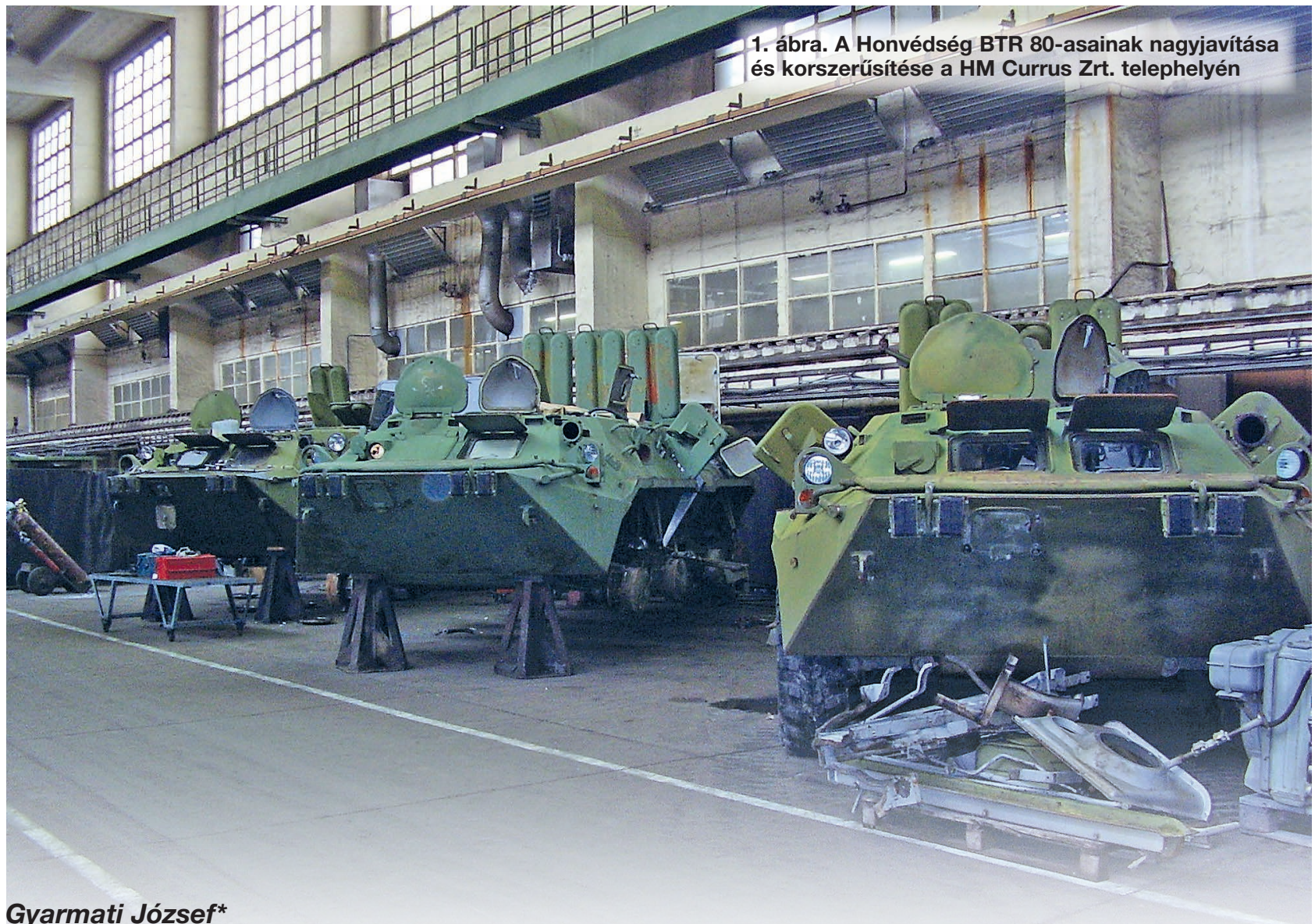

\title{
Az üzemfenntartás speciális katonai követelményei
}

\section{BeVEZzetés}

A gépek és berendezések nem rendeltetésszerű használatuk esetén - például túlterhelés -, megnövekedett valószínúséggel veszítik el részlegesen vagy teljesen a betöltött funkcióikat, vagyis meghibásodnak. A gépeket üzemeltető szervezetek a meghibásodások számának csökkentésére ún. megelőző jellegű tevékenységeket vezetnek be. A haditechnikai eszközök és alkatrészeik, üzemeltetésük során olyan fizikai, kémiai vagy biológiai változásokon mennek keresztül, amelyek eredménye még az előírt paraméterek melletti géphasználat esetében is a meghibásodás. A haditechnikai eszközök esetében nemcsak a hibamentesség a cél, hanem a hadrafoghatóság megőrzése és szinten tartá-
ÖSSZEFOGLALÁS: Az előre jól tervezhető és költséghatékony gépüzemeltetés alapfeltétele a megfelelően kialakított üzemfenntartási rendszer. Napjainkban egyre korszerübb rendszerek irányítják a gépek fenntartásának egyes müveleteit. A vezérlésben jelentős szerep jut a diagnosztikának, és a vállalatirányitási rendszerbe integrált karbantartás-irányító számítógépes megoldásoknak. A korszerű karbantartási rendszereket mind szélesebb körben integrálják a vállalati hierarchiába. A cikk a tématerülethez tartozó fogalmak definícióiból, és a katonai üzemeltetés sajátosságaiból kiindulva azon feltételeket és követelményeket vezeti le, amelyek a katonai üzemfenntartási rendszer kialakításához szükségesek.

KULCSSZAVAK: üzemeltetés, üzemfenntartás, üzemben tartás, karbantartás, karbantartásszervezés, megbízhatóság
ABSTRACT: A prerequisite for well-planned and cost-effective operation of machines is a properly established maintenance system. Nowadays, more and more sophisticated systems control certain operations of machine maintenance. Significant players in the control are the diagnostics, and the computerized maintenance control integrated into the company management system. Modern maintenance systems are increasingly integrated into the company hierarchy. Based on the definitions of the concepts in the subject area and the specificities of military operation, this article sets out the conditions and requirements necessary for the establishment of a military maintenance system.

KEY WORDS: operation, maintenance, running, servicing, organization of servicing, reliability

Okl. mk. alezredes (PhD) NKE Hadtudományi és Honvédtisztképző Kar, Haditechnikai Tanszék, tanszékvezető. ORCID: 0000-0001-7594-2383 


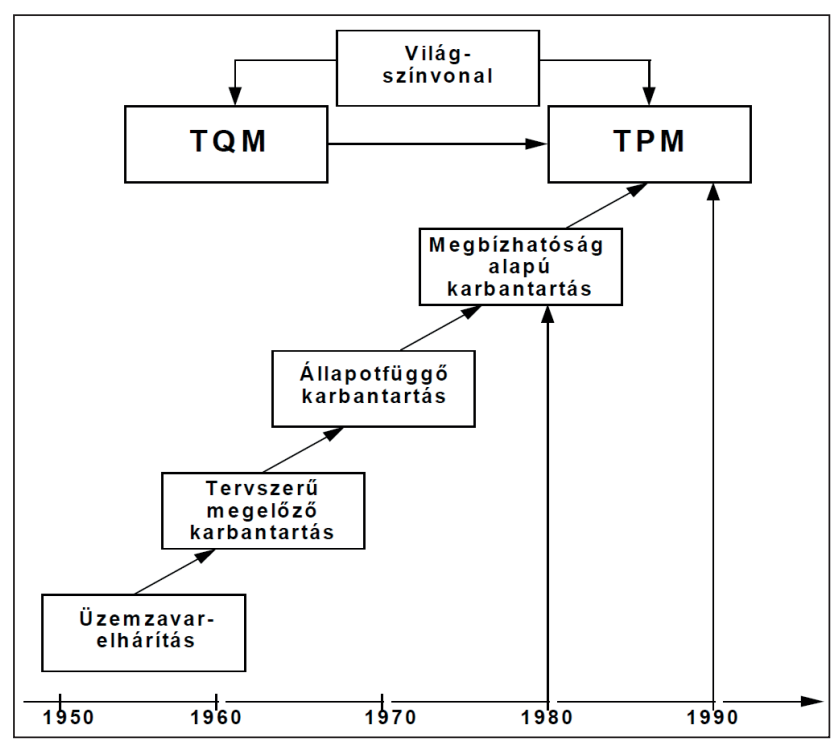

2. ábra. A karbantartási rendszerek fejlődése

sa, ezért a katonai szervezetek is végeznek megelőző jellegü tevékenységeket, amelyeket a szakirodalom többsége összességében karbantartásnak nevez. A karbantartás segítségével csökkenthető a váratlan leállások száma, a meghibásodást követő elhárítás (javítás) költsége, és növelhető a megbízhatóság, a katonai szervezet esetében pedig a hadrafoghatóság.

A karbantartás sokrétű tevékenység, ami az üzemeltetést végző szervezet több szintjét érinti. Az egyes szintekhez kapcsolódó feladatok egymásra épülnek és kapcsolatban állnak az üzemeltető szervezet többi alrendszerével. A karbantartási folyamatok elvégzése és azok irányítása ezért rendszerszintű szervezést és végrehajtást igényel.

A karbantartási rendszerek hatékony működése jelentős mértékben befolyásolja az üzemeltető szervezet fő tevékenységének minőségét, ennek következtében az elmúlt mintegy 60 évben a karbantartó rendszerek folyamatos fejlődését lehetett tapasztalni. A fejlődést foglalja össze a 2. ábra.

Az 2. ábra szerint az első rendszer (Üzemzavar-elhárítás) lényegében azt jelentette, hogy az eszközt a meghibásodásig üzemeltették, minimális megelőző jellegű tevékenységgel, például olajszint ellenőrzése, esetleges utántöltés és csere. A nemzetközi szakirodalom ezt Run to Faliure néven nevezi. A következő lépcső a Tervszerű megelőző

3. ábra. Karbantartás és javítás 1965-ből. A Magyar Néphadseregben is rendszeresített Csepel D 344-es tehergépkocsi szerelését szemléltető tabló

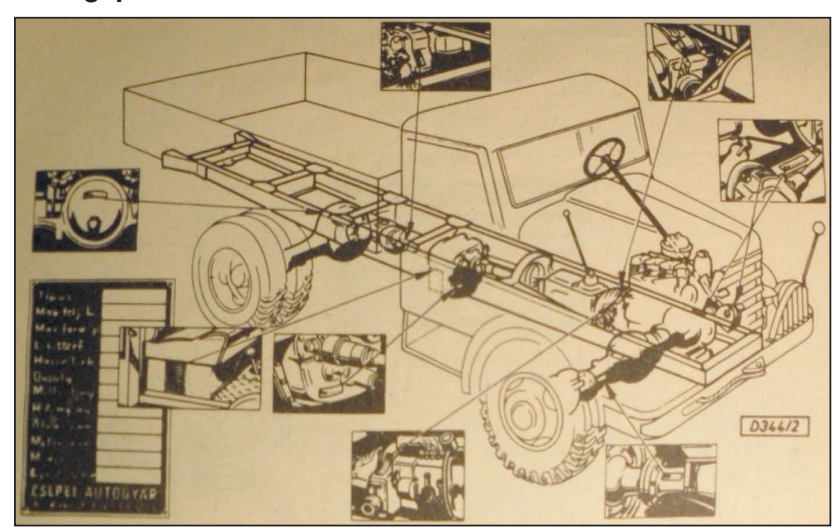

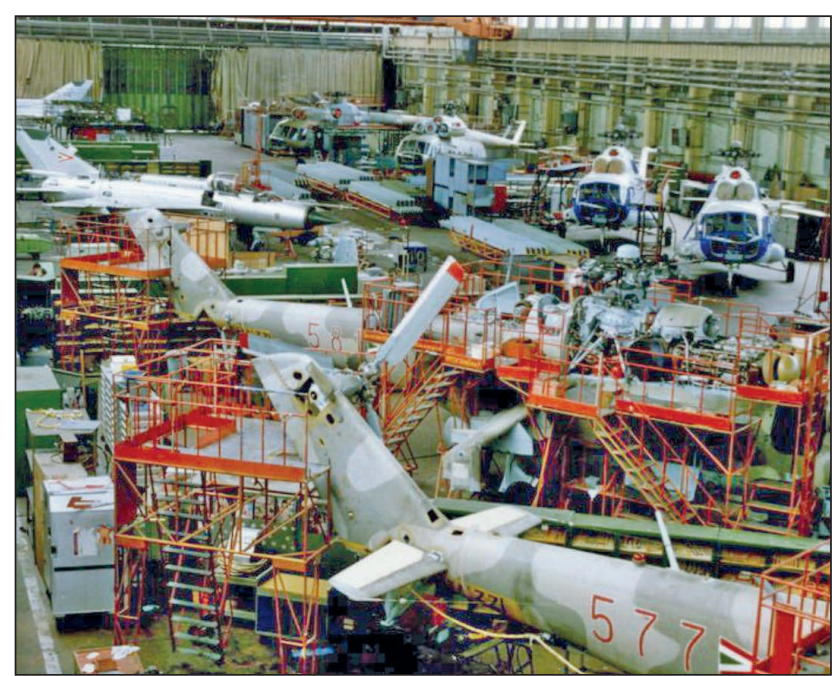

4. ábra. A tervszerū megelőző javítás egy példája. A Mi helikopterek és MiG vadászgépek ipari nagyjavítása a tököli Pestvidéki Gépgyárban az 1990-es évek elején

karbantartás (TMK, Preventive Maintanance). Ennél a rendszernél a karbantartások idejét üzemeltetési tapasztalatok alapján egy meghatározott üzemidő, üzemeltetési ciklus vagy futott kilométer segítségével határozták meg. A karbantartások idejét statisztikai-valószínűségelméleti úton határozták meg, ezt a módszert megbízhatóságelméletnek nevezi a szakirodalom $(2,3)$. Az alapvetően megbízhatóságelmélet alapú TMK alkalmazásával magas megbízhatósági szintet csak úgy lehetett elérni, ha jelentős üzemi tartalékok maradtak a berendezésekben. Az elégséges megbízhatósághoz tehát nagyon sok olyan művelet tartozott, amely során még az üzemképességet megfelelő szinten biztosítani tudó alkatrész cseréje is megtörtént, ami magas költségeket vont maga után. A rendszer hibáját javította az állapotfüggő karbantartás, vagyis a diagnosztika. Ebben az esetben a karbantartást az eszköz műszaki állapotának megfelelően végezték el. Az 1970-es és '80-as évektől folyamatosan fejlődő informatika és a vállalat vezetésben, szervezésben megjelenő új elvek hatására magasabb komplexitású karbantartási rendszerek jelentek meg, amelyek lényegesen túlnyúltak a ciklusszervezésen. Ezek a Megbízhatóság alapú karbantartás (Reliability Centred Maintenance, RCM) és a Teljeskörü hatékony karbantartás (Total Productive Maintenance, TPM) $(4,5)$. A különböző korszerű karbantartási technológiák alkalmazásához egyre több adat és információ vált szükségessé, amihez megfelelő informatikai támogatás kellett. Ez az igény hívta életre az ún. CMMS rendszereket (Computer Maintenance Management System - Számítógépes karbantartás kezelő rendszer) (6).

A karbantartás és annak szervezése olyan feladat, amely érinti az üzemeltető szervezet szinte valamennyi szintjét. Hatását tekintve pedig alapvetően befolyásolja a megbízhatóságot (hadrafoghatóságot) és a géphasználattal öszszefüggő költségeket.

A 2. ábra több korszerű karbantartási rendszert is ábrázol. Felmerül a kérdés, hogy ezen rendszereknek milyen katonai adaptációs lehetősége képzelhető el. A felhasználást megelőzően azonban ismerni kell, hogy egy katonai szervezet esetében a karbantartó rendszerrel kapcsolatban milyen általános és speciális követelményeket kell figyelembe venni. Melyek lesznek azok az alapvető szempontok, feltételek, követelmények, amelyek meghatározása a karbantartásszervezés kiindulását képezhetik. 
A cikk első részében a meghibásodás törvényszerűségeinek alapjait foglaljuk össze, majd a második részében a területtel kapcsolatos és a téma feldolgozáshoz szükséges fogalmakat definiáljuk. Az egyes fogalmak definíciójának jelentősége abban rejlik, hogy a szakirodalom ebben a kérdésben nem egységes, valamint a katonai terminológia is tartalmaz eltéréseket. A harmadik részben a karbantartó rendszer speciális katonai követelményeit határozzuk meg.

\section{A MEGHIBÁSODÁS ALAPTÖRVÉNYSZERŰSÉGEI}

A meghibásodás a (2) szerint egy olyan esemény, amely során a termék elveszíti azt a képességét, hogy az előírt funkcióit betöltse. A definíciót tovább lehet pontostani aszerint, hogy a gépeknek, berendezéseknek van egy előirt működési tartománya, ami fizikai paraméterek segítségével meghatározható. Ilyen például egy motor teljesítménye vagy egy mérőműszer pontossága. Ezen esetekben meghibásodásnak kell tekinteni azt az eseményt is, amikor a működőképesség ugyan megmarad, de a működést jellemző paraméterek az előírt határokon kívülre kerülnek. Megnő például a károsanyag-kibocsátás, vagy a müszer a saját előírt pontosságán kívül mér. A meghibásodás a kiváltó ok, a meghibásodás teljességének a mértéke, vagy időtartama szerint tovább csoportosítható. Az okoktól függetlenül maga a meghibásodás egy biztosan bekövetkező eseménynek tekinthető, amely statisztikai módszerekkel is leírható. A megbízhatóság-elméletben a meghibásodások bekövetkezését normál, exponenciális, Weibull-, és lognormális eloszlás segítségével írják le (3). Normál eloszlással bekövetkező meghibásodás sűrűségfüggvényét mutatja a 5. ábra.

Egy alkatrész elhasználódása, amely a gép meghibásodását okozhatja, például kopás vagy anyagfáradás miatt, normál eloszlást mutat. Az alkatrész-elhasználódás miatti meghibásodás valószínűséget az (1) egyenlet segítségével lehet számítani, amennyiben a 5 . ábra szerinti eloszlásfüggvény a megfelelő pontosággal ismert.

$$
p_{h}=P\left(0 \leq \tau \leq t_{k}\right)=\int_{0}^{t_{k}} f(t) d t,
$$

ahol $p_{h}$ a meghibásodás valószínúsége $t$ időpontig. Az alkatrész meghibásodásának a valószínűsége a $t_{k}$ időpontig megegyezik a görbe alatti terület nagyságával 0 és $t_{k}$ között. A függvény definiálásához szükséges az eloszlás, és annak paramétereinek az ismerete: $N(\mu, \sigma)$ vagyis a várható érték és a szórás. Az (1) egyenlet szerint a meghibásodás valószínűsége az üzemidővel növekszik és $t=\mu+3 \cdot \sigma$ időpontig

$$
P(\tau<\mu+3 \cdot \sigma)=0,997
$$

\section{5. ábra. Normál eloszlás sürüségfüggvénye}

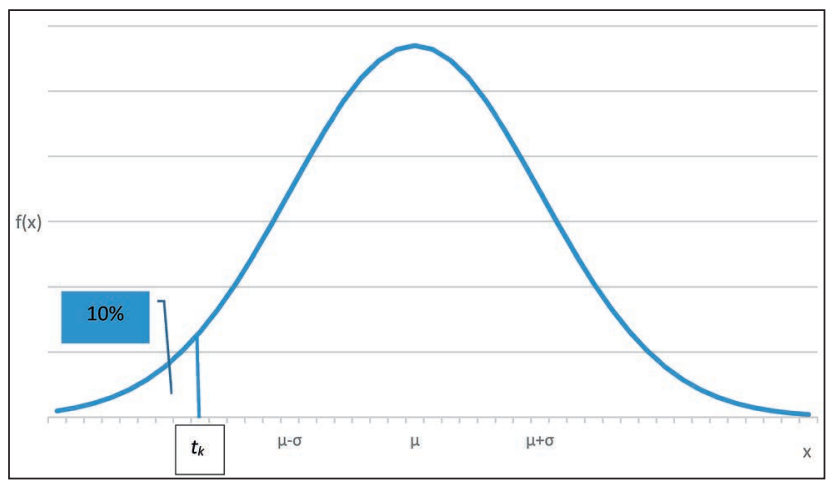

valószínűséggel következik be. A függvény szerint tehát csak valószínűsíteni lehet a meghibásodást. Ennek komplementer eseménye, hogy az eszköz addig nem hibásodik meg. A meg nem hibásodás valószínüségét $t_{k}$ időpontig a 5. ábra és az (1) egyenlet segítségével lehet meghatározni:

$$
p_{u ̈}=p\left(\tau \geq t_{k}\right)=\int_{t_{k}}^{\infty} f(t) d t
$$

ahol $p_{\text {ü }}$ a meg nem hibásodás valószínűsége $t_{k}$ időpontig.

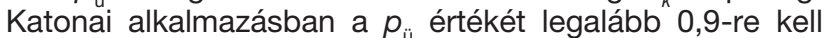
venni, ami azt jelenti, hogy az eszközök legalább 90\%-a üzemképes. Ebben az esetben olyan karbantartási időpontot kell választani, ahol a $p_{h}=0,1$ és a meghibásodás valószínúsége $10 \%$. A 5 . ábra mutatja ezt a pontot, ami jól láthatóan a $\mu$ várható értéktől jóval balra helyezkedik el, és olyan alkatrész cseréjét is maga után vonhatja, ahol még jelentős az üzemi tartalék.

A karbantartási ciklusidő kiválasztása tehát jelentősen befolyásolja a költségeket. Amennyiben növekszik a ciklusidő, vagyis a karbantartásokat ritkábban hajtják végre, akkor csökken a karbantartások költsége, nő azonban a váratlan meghibásodások száma, és ezek költsége. Ez felveti azt a gondolatot, hogy a hadrafoghatóság mellett célszerű a költséghatékonyság szerint is megvizsgálni a ciklusidők meghatározását.

A gazdaságossági megközelítéshez ismerni kell az ide vonatkozó költségösszetevőket. A váratlan meghibásodás költségei három csoportba oszthatók:

1. A hiba elhárításának közvetlen költségei:
a) munkadíj;
b) anyagköltségek;
c) szállítási költségek.

2. A meghibásodás közvetett költségei:

a) másodlagos károk elhárításának költségei;

b) sérült személyek rehabilitációjának költségei;

c) perköltségek

3. A meghibásodás miatt a termelésből (kiképzésből) való kiesés költségei:

a) sérülések miatt a munkaerő kiesésének költségei;

b) a gép termelésből (kiképzésből, feladatvégrehajtásból) történő kiesés költsége.

A karbantartások költségei:

1. Közvetlen költségek:
a) munkadíj;
b) anyagköltségek;
c) amortizáció;
d) szállítási költségek.

2. Közvetett költségek:

a) szállítási költségek;

b) a gép termelésből (kiképzésből, feladatvégrehajtásból) történő kiesésének a költsége.

Összességében tehát a meghibásodás, megelőző jellegű tevékenység nélkül egy biztosan bekövetkező eseménynek tekinthető, amelynek több költségösszetevője van. Ennek megelőzése vagy a számuk, illetve a hatásuk csökkentése érdekében bevezetett tevékenységeknek szintén több költségösszetevőjük van. A váratlan meghibásodás jelentős mértékben megnehezíti a géphasználat tervezését, hiszen előre csak rosszul, pontatlanul valószínüsíthető, hogy mennyi eszköz lesz működőképes egy meghatározott időintervallumban. Ez pedig, figyelembe véve az eloszlásokhoz tartozó szórások esetlegesen magas értékeit, akár az előre betervezett feladatok elégtelen végrehajtását vagy a végrehajtás elmaradását vonhatják maguk után. Katonai üzemeltetés esetében ez alapvetően befolyásolja a kiképzés minőségét, súlyosabb esetekben pedig a honvédelmi feladatok ellátását. 


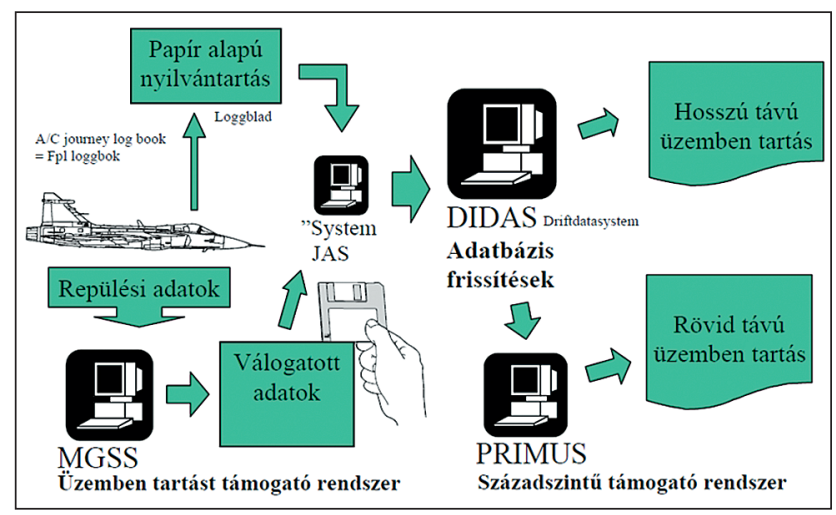

6. ábra. A svéd Saab Gripen vadászgépnél már a tervezésekor fontos szempont volt a hálózatba kötött számítógépes karbantartás-kezelő rendszer alkalmazása. A Magyar Honvédségben szolgáló Saab JAS 39 EBS HU-k üzemeltetése és karbantartása is ennek a szoftvernek a felhasználásával történik

A meghibásodás tehát egy olyan esemény, amely:

- magas közvetlen és közvetett költségekkel rendelkezik;

- befolyásolja a géphasználat, vagyis az üzemeltetés tervezését;

- befolyásolja a gépet üzemeltető szervezet működésének a minőségét.

Következmény lehet a gépet használó intézmény vagy gazdasági társaság számára a cég feladatrendszerének ellátásában bekövetkező komoly hiányosság. Katonai szervezet esetében ez hiányos vagy akár elégtelen kiképzést is eredményezhet, ami a katonai szervezet harcképességét is komoly mértékben befolyásolhatja.

\section{Alapfogalmak}

A gépek előirt paramétek szerinti működőképességét több tényező befolyásolja. Az MSZ IEC 50 ezt a megbízhatóság fogalmával definiálja. A szabvány szerint a megbízhatóság a használhatóság és az azt befolyásoló tényezők leírására szolgál. A használhatóság a termék azon képessége, hogy az előírt funkcióit egy adott időszakaszban ellátja, de ehhez feltételeket szab, amelynek értelmében a funkciók betöltéséhez szükséges külső erőforrások a rendelkezésre állnak. A feltételek a hibamentesség, a karbantarthatóság, és a karbantartásellátás. A szabvány megemlíti a karbantartást, amelyet a szakirodalom nem egységesen definiál, jelen esetben karbantartáson azon megelőző jellegű tevékenységet kell érteni, amelyet a hibamentesség szinten tartása érdekében végeznek.

Ahhoz tehát hogy egy eszköz az üzemeltetési (katonai) célokból fakadó elégséges megbízhatósággal rendelkezzék, nem elegendő magának az eszköznek a vizsgálata. A vizsgálatnak a következőkre kell kiterjednie.

- Az eszköz műszaki tulajdonságaira:

- milyen élettartamot garantál a gyártó, és ezt a termék milyen valószínűséggel teljesíti;

- hogyan lehet előre jelezni az egyes alkatrészek elhasználódását (a diagnosztika alkalmazhatóságának a mértéke);

- milyen műszaki összetettségűek az egyes megelőző jellegű tevékenységek (elhasználódott alkatrész cseréje, kenőanyag csere, beállítások).

- A megelőző jellegü tevékenységet végző szervezetre: - karbantartó személyzet megléte és felkészültsége;

- karbantartáshoz szükséges felszerelés megléte;

- kommunikáció a termék gyártójával és felhasználójával.

- Az eszközt üzemeltető szervezetre:

- az eszközzel kapcsolatos képzési rendszer minősége;

- az eszközt használók felkészültsége;

- az eszköz használat tervezésének minősége;

- az eszköz használatra vonatkozó előírások betartásának fegyelme;

- a karbantartási folyamatok illesztésének a minősége és szintje a szervezet belső szabályozási rendszerében;

- informatikai rendszer minősége.

A felsorolásból látható, hogy a megbízhatóság összetett, és nagyon sok tényezőtől függ. A felsoroláshoz kiegészítésként még hozzá kell adni, hogy a karbantartást végző szervezet lehet az üzemeltető szervezet része, de lehet külső is. Alkalmazható a kettő kombinációja is, amikor a karbantartást egy meghatározott technológiai szintig az üzemeltető és egy adott szint után pedig egy erre szakoso-

7. ábra. Az ábrán a Magyar Honvédség MAN TGS 40.540 6×6 BBS MIL vontatója Goldhoffer STZ-H 6 nehéz félpótkocsival. A $74000 \mathrm{~kg}$ teherbírású szerelvénnyel a rendszeresítés alatt álló Leopard 2-es harckocsi és PzH 2000 önjáró löveg is gazdaságosan szállítható

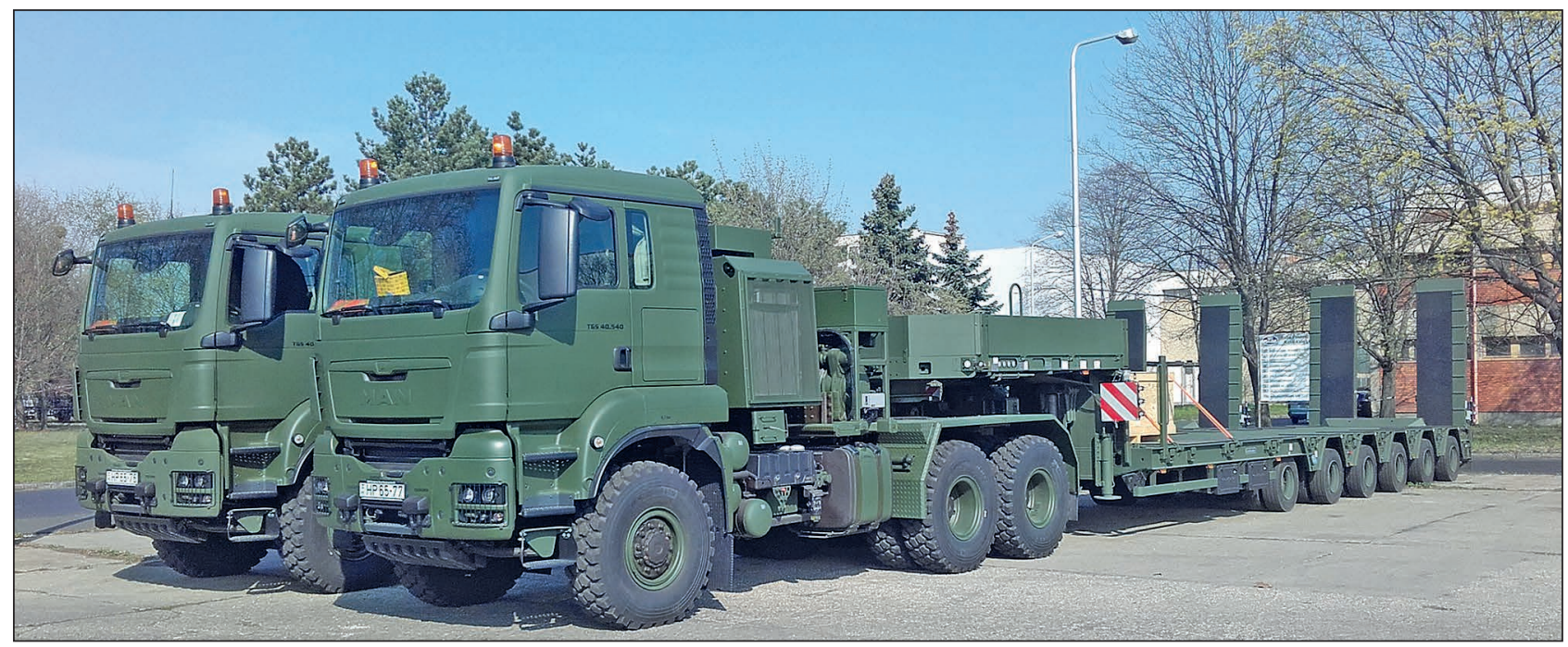


dott külső cég valósítja meg. A karbantartást végző szervezet kiválasztásánál (saját vagy külső) figyelembe kell venni a következő szempontokat azzal a kitétellel, hogy a gépkezelőnek mindig van valamilyen karbantartási feladata, például a tisztítás és az igénybevétel előtti ellenőrzés.

A karbantartást (javítást) végző szervezet kiválasztásnál a következőket kell figyelembe venni:

- költség;

- állásidő (milyen gyorsan képes fogadni és mennyi idő alatt végzi el a szükséges múveleteket);

- kommunikáció (hány külső céggel kell tartani a kapcsolatot);

- tervezhetőség (több külső cég esetén hogyan lehet tervezni);

- a karbantartás külső helyszínre helyezése mennyire veszélyezteti az üzemeltető szervezet céljait.

A megbízhatóság tehát rendszerszinten vizsgálandó feladat, amelyhez az idetartozó rendszerszintű fogalmakat kell definiálni.

A komplex üzemfenntartás a (7) szerint:

- az állóeszköz-gazdálkodás (aktiválás - üzemeltetés selejtezés)

- karbantartás, karbantartás-irányítás

- a szinten tartó beruházások (állóeszközpótlás) funkciókban fogalmazható meg.

A (8) megkülönböztet üzemben tartást és üzemfenntartást. Az üzemben tartás felosztható:

- megelőző jellegű tevékenységekre és

- elhárító jellegű tevékenységekre.

A megelőző jellegű tevékenységeket a még működőképes eszközökön végzik azzal a céllal, hogy a váratlan meghibásodások valószínűségét csökkentsék, illetve egy előre meghatározott szintre állítsák vissza. Ezt nevezzük karbantartásnak és megelőző javításnak. A tevékenység során általában statisztikai adatokra támaszkodva végzik el a különböző alkatrészek, kenőanyagok cseréjét és a gép, illetve berendezés működési paramétereinek ellenőrzését, beállítását.

Az elhárító jellegű tevékenységet működésképtelen eszközön végzik azzal a céllal, hogy a hibamentességet újra elérjék. Ezek nevezzük javításnak.

Az üzemfenntartás a (8) szerint magába foglalja a haditechnikai biztosítást lehetővé tévő:

- technikai;

- gazdálkodási és

- adminisztratív feladatokat.

Az üzemfenntartást tehát egy tágabb fogalomként kezeli, amelynek része az üzemben tartás, amely a karbantartást, mint megelőző jellegű tevékenységet, és a javításokat, mint elhárító jellegű tevékenységeket foglalja magába (8).

A ([8] 2. old.: 206.) az üzemfenntartást és a karbantartást egyszerre kezeli, csak a karbantartás fogalmát definiálja múszaki és adminisztratív tevékenységként, amelynek célja, hogy a gépeket és berendezéseket az előírt funkciójának teljesítésére alkalmas állapotban megtartsák, illetve ebbe az állapotba visszaállítsák. Ebben a megfogalmazásban az üzemfenntartás fogalma részben fedi a (8) szerinti definíciót, azzal a kitétellel, hogy a (8) az üzemfenntartást a karbantartástól külön definiálja, és a gazdálkodási feladatokat is idetartozónak veszi.

A vizsgálat alapvetően a katonai szervezetek megbízhatóságára vonatkozik, ezért a továbbiakban az üzemfenntartás és az üzemben tartás (8) szerinti értelmezését veszszük figyelembe.

A további rendszervizsgálat a katonai szervezet megbízhatóságát meghatározó, egyben komplexebb fogalomra, az üzemfenntartási rendszerekre fókuszál.

\section{A KATONAI ÜZEMFENNTARTÁS}

Az üzemben tartás a kiválasztott definíció szerint csak a karbantartásokat és a különböző szintű javításokat foglalja magába, míg az üzemfenntartás egy tágabb fogalom, amely magába foglalja az üzemben tartást és az ezzel kapcsolatos egyéb technikai, szervezési és adminisztratív tevékenységeket, valamint a gazdálkodási tevékenységeket is. A rendszervizsgálat során tehát a komplexebb üzemfenntartást kell tovább vizsgálni. A vizsgálat további célja azon katonai követelmények összeállítása, amelyek a katonai képességek eléréséhez és elégséges szinten tartásához alkalmas üzemfenntartási rendszerre vonatkoznak.

A követelményekhez a katonai üzemeltetés igényein keresztül lehet eljutni. A katonai üzemeltetés nem állandó intenzitású. A kiképzési, illetve felkészülési időszakban jellemző az üzemeltetés alacsony mértéke. Gépjárművek esetén ez éves szinten, eszközönként a civil haszonjármüvek futásteljesítményének tizedét-századát jelenti. Az egyes eszközök futásteljesítményeinek a szórása azonban jelentős lehet. Minősített időszakban az üzemeltetés mértéke akár nagyságrendekkel is megnőhet. Fontos katonai jellemző, hogy az üzemeltetés mennyiségi növekedésére vonatkozó igény nem minden esetben jelezhető előre. Tudni lehet, hogy mikor lesz katonai gyakorlat, ami szintén megemeli a géphasználat mennyiségét, de előre nem tudható, hogy a minősített (éles) helyzetek mikor következnek be. Az üzemfenntartási rendszernek tehát kezelnie kell egy alacsony és egy magas intenzitású géphasználatot is. Emellett, a korlátozott előrelátás miatt kezelnie kell azt a szituációt, amikor ismert időpontra és időintervallumra kell adott szintre emelni a megbízhatósági szintet. Ezen kívül rendelkeznie kell azzal a képességgel is, hogy a nevezett megbízhatósági szintet váratlan időpontban kell emelnie egy előre meghatározott szintre.

Egy katonai szervezet az eszközparkját tekintve rendkívül összetett. A rendszeresített és a feladatok ellátásához szükséges haditechnikai eszközök száma nagy, típusa sokféle. Az üzemfenntartási rendszernek tehát rendkívül sokféle eszköz kiszolgálását kell elvégeznie és a tevékenységet megszerveznie. Ez rögtön felveti a külső erőforrások igénybevételének lehetőségét, ami lehet például maga a gyártó vagy annak valamilyen karbantartást ellátó alvállalkozója. A korábbi definíció értelmében az egyes eszközök technikai kiszolgálása és a technikai kiszolgálás megszervezése nem azonos az üzemfenntartási rendszerrel, ez legfeljebb annak alrendszere lehet, amit illeszteni kell a förendszerbe, vagyis a katonai szervezethez. Az üzemfenntartási rendszernek lényegében ezt az illesztést kell elvégeznie az alrendszerek összefogásával. Ezt mutatja a 8. ábra, amely szerint az üzemfenntartás szervező, vezető és irányító alrendszerének célszerűen a katonai szervezeten belül kell maradnia. Ezzel a megoldással ugyanis ez az alrendszer képes összefogni az egyes eszközök technikai kiszolgálásának és javításnak folyamatát. Egy szervezeten belül összpontosul az üzemfenntartással kapcsolatos információ, ami ennek megfelelően képes megfelelően kapcsolódni a katonai szervezet megfelelő alrendszereihez (alegység, logisztika, hadművelet, parancsnokság). Ennek megfelelően a katonai szervezet közvetlenül képes irányítani az üzemfenntartó rendszert, és az a megfelelő felhasználói (katonai) információk birtokában képes a saját alrendszereit vezetni a katonai szervezet érdekében és annak elvárásai alapján. Az egyes eszközök technikai kiszolgálását elvégezheti a saját katonai szervezet, de a követelményeknek megfelelő külső erőforrás is igénybe vehető. 


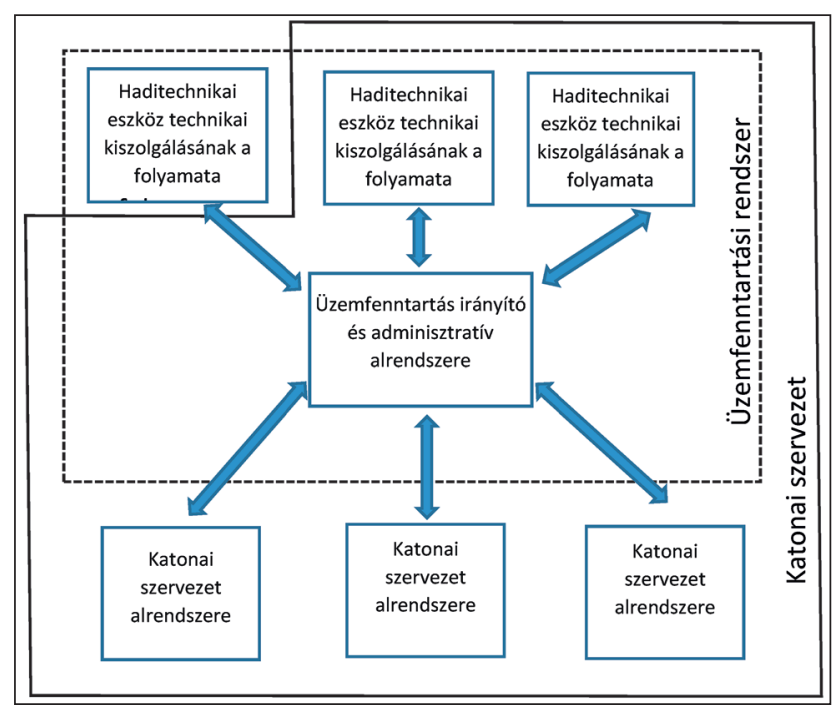

8. ábra. Az üzemfenntartási rendszer elhelyezkedése a katonai szervezetben

A megbízhatóság fogalma segítségével további speciális katonai követelmények határozhatók meg az üzemfenntartási rendszer irányában. A megbízhatóság az MSZ IEC 50 szerint termék- és karbantartó szervezet függő. Az előírt megbízhatósági (hadrafoghatósági) szinthez tehát nemcsak megfelelő minőségű eszközre van szükség, amely a műszaki és gyártási-szerelési színvonalából adódóan csak elfogadható valószínűséggel hibásodik meg. Ahogy azt korábban tisztáztuk, a múszaki állapot idővel romlik, tehát bármely műszaki színvonalon előálított eszköz állapota megelőző jellegű technológiák nélkül leromlik, vagyis karban kell tartani. A karbantartó rendszernek - mint az üzemfenntartási rendszer alrendszerének -, erre a megfelelő időben és megfelelő mennyiségben megfelelő erőforrásokat kell a rendelkezésére bocsátani. Katonai viszonylatban mindkét tényezőnek nagy jelentősége van. A katonai üzemeltetés jellegzetességei miatt, az üzemfenntartási rendszernek állandóan készen kell állnia a megnövekedett intenzitású üzemeltetés bekövetkezésének kezelésére. Az erőforrások rendelkezésre bocsátásának tehát adott időhatárokon belül kell megtörténnie.

Az üzemfenntartási rendszerrel kapcsolatban a következő általános célokat lehet megfogalmazni a ([8] 2. old. 203.) szerint:

- a megfelelő szintű megbízhatóság elérése;

- a váratlan meghibásodásokból eredő állásidők csökkentése;

- a karbantartások elvégzése miatti állásidők csökkentése;

- a költségek optimálása.

Az általános követelmények, valamint a speciális katonai igények alapján a katonai szervezetek esetében az üzemfenntartási rendszerre vonatkozó követelményeket a következőképpen lehet összefoglalni:

- A rendszer legyen képes azt a megbízhatóságot biztosítani, amely a katonai szervezet előírt feladatai végrehajtásához minimálisan szükséges:

- legyen képes az eszközök állandó megbízhatóságát produkálni;

- legyen képes egy adott feladat elvégzésére akár emelt szintű megbízhatóságot produkálni.

- A rendszer illeszthető legyen a katonai szervezet jogi és belső szabályozási rendszerébe:

9. ábra. A Magyar Honvédség 20 darab Airbus H145M helikoptert rendszeresít. A típus polgári változatát széles körben használják a civil szolgálatok is, így célszerű lehet az üzemeltetési és karbantartási tapasztalatok megosztása.

(A H145 típusról készült angol nyelvű ismertető)

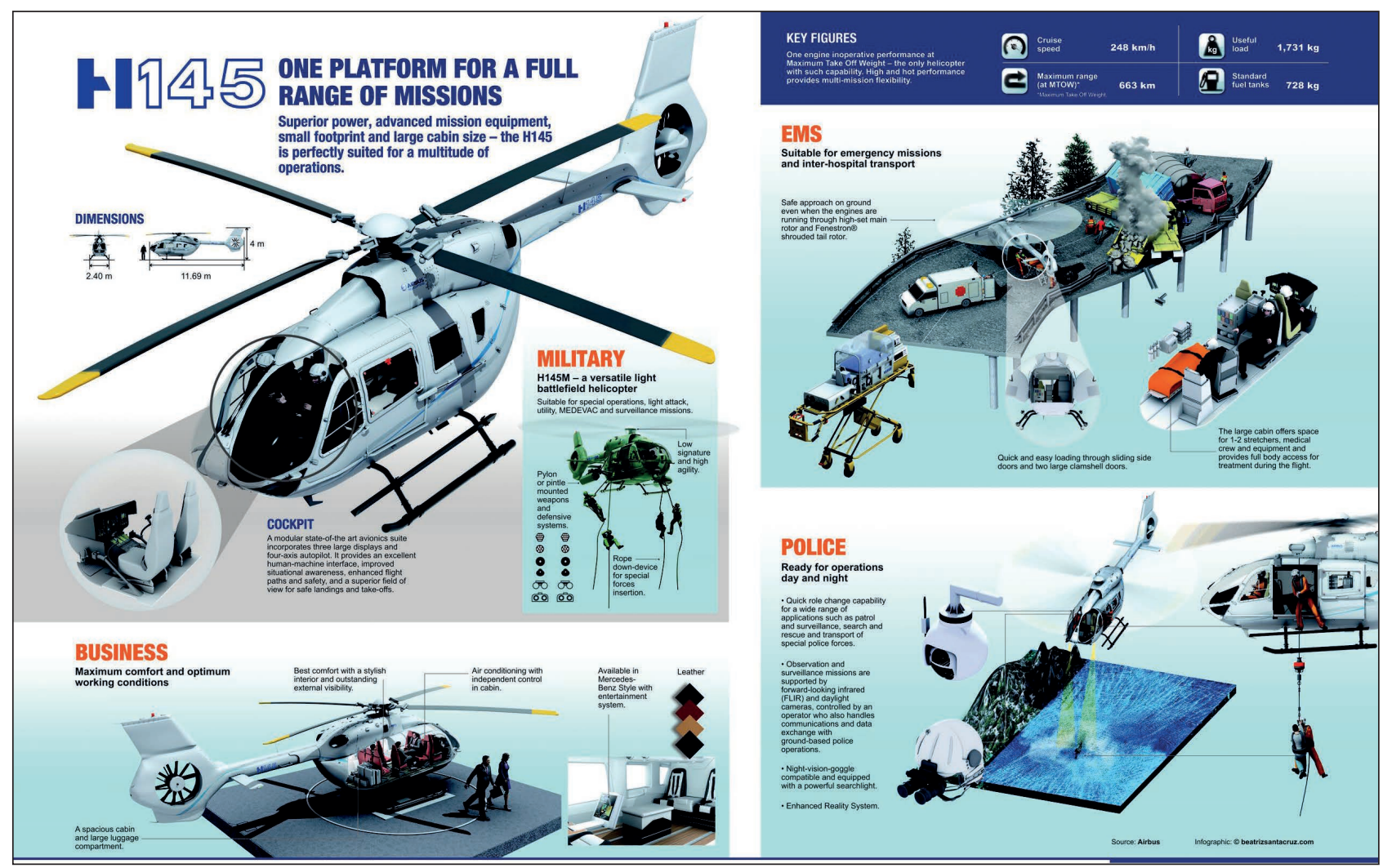




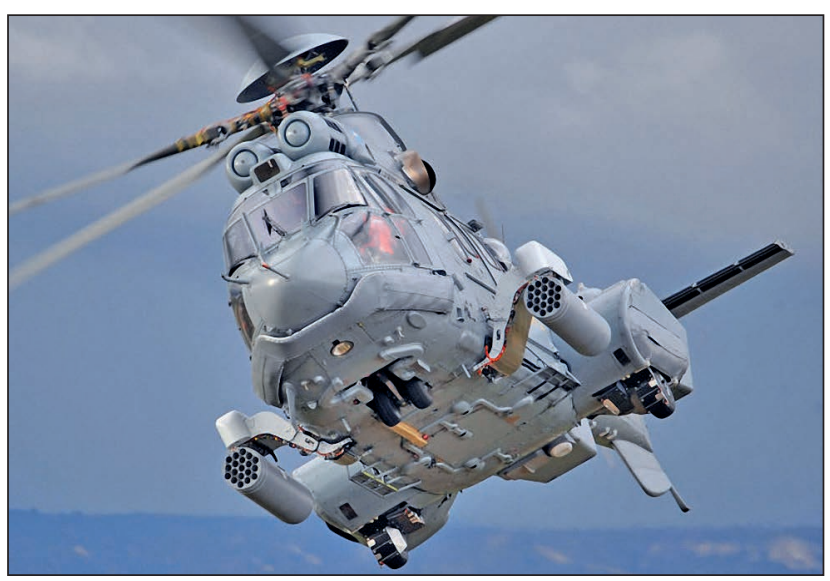

10. ábra. A Magyar Honvédség 16 darab Airbus H225-ös helikoptert rendszeresít a Zrínyi 2026 program keretében. Az Airbus helikopter karbantartását fedélzeti diagnosztika segíti (OBD)

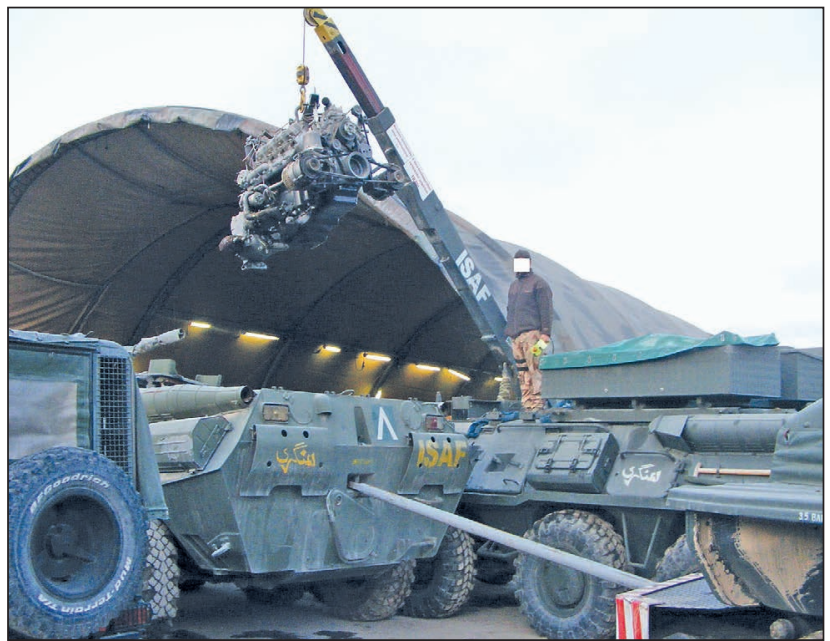

11. ábra. A katonai jármúvek igénybevétele békeidőben általában kisebb, mint a polgári eszközöké, minősített időszakban viszont az üzemeltetés mértéke akár nagyságrenddel is megnőhet. A képen BTR $80 \mathrm{~A}$ motorcseréje látható tábori körülmények között

- a tervezhetőség és az eredményes végrehajtás érdekében az üzemfenntartási rendszer irányításával kapcsolatos feladatok legyenek hozzárendelhetők a parancsnoki hierarchia különböző szintjeihez;

- az üzemfenntartásba minél szélesebb kört vonjanak be;

- a katonai szervezet legyen képes az üzemfenntartási rendszer valamennyi elemét parancsnoki utasításos, vagy szerződéses úton elérni.

- A rendszer legyen képes kielégíteni a katonai szervezet üzemeltetés-tervezésre és az eszközök elérhetőségére vonatkozó igényeit;

- a rendszer az erőforrásait megfelelő garanciákkal legyen képes a katonai szervezet rendelkezésére bocsátani;

- a katonai igények szerint rendelkezzen megfelelő rugalmasággal.

- A rendszer legyen rugalmas:

- a rendszer az erőforrásait a katonai igényeknek megfelelően legyen képes rendelkezésre bocsátani.

- A rendszer legyen költséghatékony.

Az üzemfenntartási rendszert tehát négy szempont szerint lehet jellemezni:

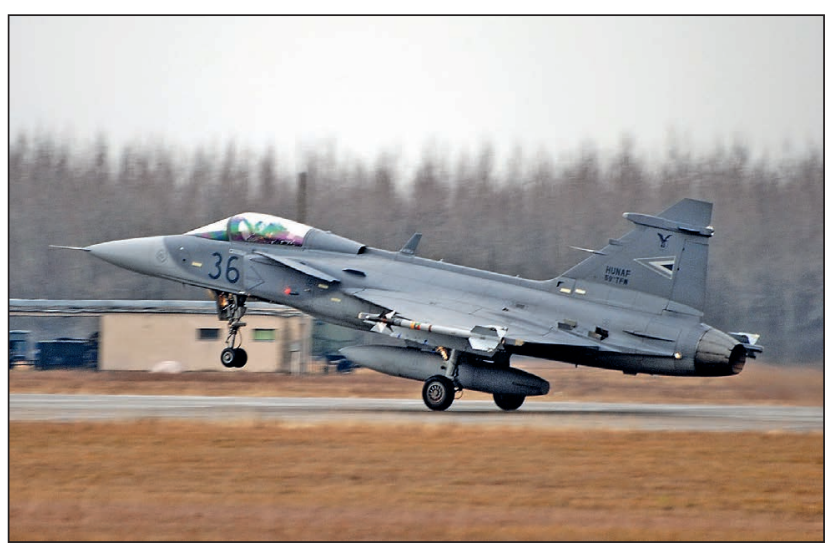

12. ábra. Készültségi szolgálatban lévő Gripen riasztást követő felszállása. A magyar légierő a NATO egyesített légvédelmi rendszere (NATINADS) 24 órában tart légvédelmi készültségben Gripen géppárt. A feladat elvégzéséhez magas megbízhatósági szint tartozik

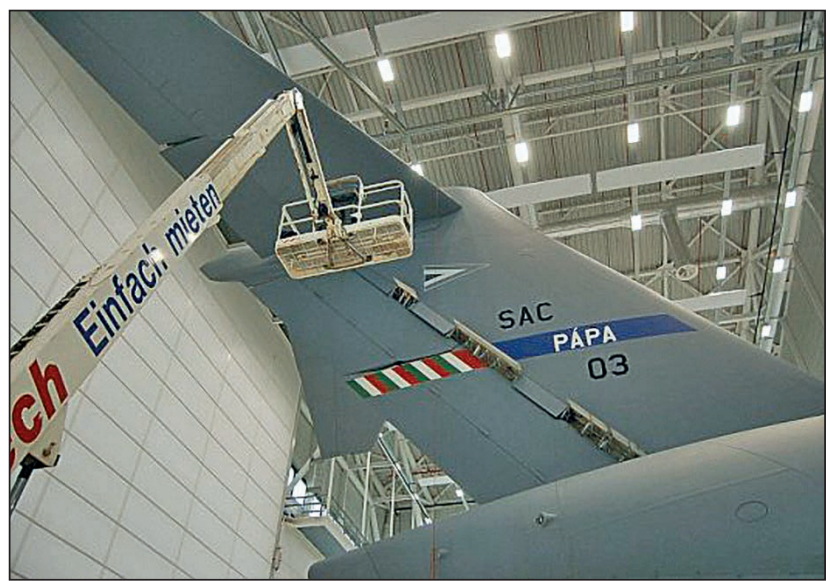

13. ábra. A NATO nehéz légiszállító ezred magyar felségjelü C 17-es szállító repülőgépének nagy méretű függőlleges vezérsíkját emelőkosaras kocsival ellenőrzik az új pápai hangárkomplexumban. A fedett, klimatizált épület és a speciális berendezések költséghatékonyabbá tették a nehéz szálító repülőgépek üzemeltetését, mert a karbantartási munkálatokra nem kell az Egyesült Államokba repülni

- a szolgáltatott megbízhatóság;

- illeszthetőség;

- elérhetőség;

- költséghatékonyság.

\section{ÖSSZEFogLaLÁs}

Összefoglalásként megállapítható, hogy egyértelműen meghatározhatók az üzemfenntartási rendszerre vonatkozó speciális katonai követelmények. Ezen követelmények alapvetően a változó intenzitású és a váratlan katonai feladatokból adódó, előre nem tervezhető gépüzemeltetésből fakadnak. Következő fontos katonai specialitás a katonai szervezeteknél használatban lévő nagy típusmennyiség. Egy katonai szervezet valamennyi rendszeresített haditechnikai eszközére vonatkozó üzemfenntartási feladatot nem tudja feltétlenül ellátni. Ennek az oka a nagy típusmennyiség, amelynek a technikai kiszolgálására és egy meghatározott szintű javítására alkalmas kiszolgáló apparátus rendkívül költséges, és egyes kis darabszámban rendszeresített eszközöknél alacsony kihasználtságú 
lenne. Ebből adódóan látni kell, hogy külső erőforrások igénybevételére szükség van. A külső erőforrásoknak viszont meg kell felelniük azon katonai követelményeknek, amelyek a katonai üzemeltetés sajátosságaiból adódnak. Az üzemeltetés katonai igény szerinti biztosítása ugyanis alapvető feltétele a katonai feladatok (harc, béketámogató, katasztrófaelhárító és humanitárius) ellátásának.

Ezeket a feltételeket speciálisan kialakított katonai üzemfenntartási rendszer segítségével lehet végrehajtani. A rendszernek a katonai szervezet egyik alrendszerének kell lennie, ugyanis ez fogja biztosítani a megelőző és az elhárító jellegű tevékenységek katonai igények szerinti megszervezését.

\section{IRODALOM}

\section{Kövesdi J., Erdei J., Tóth Zs., Eigner P., Jónás T:} Kockázat és Megbízhatóság. BMGE GTK Menedzsment és Vállalatgazdaságtan Tanszék, Oktatási segédlet 2010.; 2. Gaál Zoltán és Kovács Zoltán: Megbízatóság, karbantartás. Veszprém, Veszprémi Egyetemi Kiadó, 1998.;
3. Schaefer, Eugen: Megbízhatóság az elektronikában. Budapest, Múszaki Könyvkiadó, 1983.

4. Murthy, D.N.P., Atrens, A. és Essleston, J. A.: Strategic maintenance management, Journal of Quality in Maintenance Engineering: 2002., 8(4), 287-305. o. https://doi.org/10.1108/13552510210448504;

5. McKone, K.E., Schroeder, R.G. és Cua, K.O. Total productive maintenance: a contextual view Journal of Operations Management, 1999., 17(2), old.: 123-144. o. https://doi.org/10.1016/s0272-6963(98)00039-4;

6. Wienker, M és Ken and Volkerts, Jacques. The Computerized Maintenance Management System an Essential Tool for World Class Maintenance Procedia Engineering, 2016., 138. old.: 413-420. o. https://doi.org/10.1016/j.proeng.2016.02.100;

7. Falmann László és Cs. Nagy Géza: Üzemfenntartás. Pécsi Tudományegyetem, Pollack Mihály Műszaki Főiskolai Kar, Gépszerkezettan tanszék, 2004.;

8. Szabó József (szerk): Magyar Hadtudományi Lexikon. Budapest, MHTT, 1995.;

9. Péczely Csaba: $A$ karbantartás-menedzsment korszerü irányzatai és módszerei. 2009. 5. Magyar Grafika 2009 5. 12-16. o.

\section{Fischer Ferenc}

\section{A kétpólusú világ 1945-1989}

A Dialóg Campus Kiadó a Nemzeti Közszolgálati Egyetem kiadójaként jelentette meg 2014ben Fischer Ferenc: $A$ kétpólusú világ című hiánypótló biztonságpolitikai monográfiáját. Prof. dr. Fischer Ferenc történész, az MTA doktora, a PTE BTK Történettudományi Intézet igazgatója, az ezredforduló után a Zrínyi Miklós Nemzetvédelmi Egyetemen szervezett vezérkari tanfolyamok rendszeres előadója. A könyv szakszerűen idézi fel a kelet-nyugati hidegháborús konfrontációt, illetve a nem csak európai színtéren zajlott szovjet-amerikai rivalizálást, a bipoláris világ születésének részletes leírását adva. Haditechnikai szempontból is rendkívül figyelemre méltó a levegőben, a víz alatt, a szárazföldön és az űrben folytatott széleskörű fegyverkezési és atomütőerő verseny főbb állomásainak ismertetése. A hadiipari csúcstechnológia: az atom-tengeralattjárók, szuperszonikus vadász- és bombázó repülőgépek, az interkontinentális rakéták és a gázturbinás harckocsik, illetve a cirkáló robotrepülőgépek és a lopakodó repülőgépek világa ez. A minden addiginál magasabban repülő, tehát vadászgépekkel elfoghatatlan U-2-es kémrepülőgépek és az azokat lelövő, minden korábbinál nagyobb hatómagasságú, lokátor-vezérelt légvédelmi rakéták világa, amelyet a csillagháborús korszak űrfegyverkezési hulláma zárt le. Vietnám világa ez a helikopteres légimozgékonyság megjelenésével, és az arab-izraeli háborúk világa, az esetenként Kurszkhoz fogható méretű harckocsicsatákkal. Méltán válthatja ki mindez a Haditechnika olvasóinak figyelmét. A kötet bővebben tárgyalja a hadtudományhoz szervesen kötődő geopolitikai, geostratégiai, hadászati, haditengerészeti kérdéseket, illetve az Európán túlmutató globális katonapolitikai és diplomáciai összefüggéseket is. A könyv első fejezete az 1941 és 1947 közötti eseményeket tárgyalja az „elbai kézfogástól” a Truman-doktrína létrejöttéig. A nagyhatalmak helyzetének elemzése mellett a könyv kitekint a gyarmati rendszer szétesésére és a „harmadik világ” születésére is. A második fejezet a „klasszikus” hidegháború korszakát tárgyalja 1947 és 1962 között. Ez a korszak a karibi rakétaválságig húzódott, és már-már atomháborúval fenyegette a világot. A harmadik fejezet a „békés egymás élés” korszaka felé haladásról, az átmenet éveiről tudósít 1962 és 1969 között. A negyedik fejezet az enyhülés korszakával foglalkozik, egészen 1975-ig. Az ötödik fejezet az enyhülés megtorpanásáról tudósít, egészen a „kis hidegháború” időszakáig (1979-1985), erre leginkább a Szovjetunió afganisztáni intervenciója adott okot. Ekkor már pattanásig feszült helyzet alakult ki Európában is: vajon a Szpecnaz diverziós egységekkel és gépesített légideszantokkal támogatott szovjet hadműveleti manővercsoportok jutnak-e el elsőként Párizsig, vagy az USAF A-10-es csatarepülőgépei és AH-64-es csatahelikopterei kerülnek fölénybe a szovjet harckocsiáradattal szemben? És eközben kitör-e az atomháború? Az utolsó két fejezet - Gorbacsov peresztrojkájától a berlini fal leomlásáig, illetve a szovjet birodalom széthullásáig - a bipoláris világ 1989-es széteséséig követi és elemzi az eseményeket. A könyvben forrásjegyzék - dokumentumgyűjtemény - is található, valamint a számos fekete-fehér ábra, illetve színes térképtábla, történelmi atlaszként segíti a hidegháború történetének megértését. A monográfia magas színvonalára jellemző, hogy a vezérkari tanfolyamok kötelező olvasmányává vált.

A 456 oldalas, 8500 Ft-os árú cérnafüzött, keménytáblás A/4 formátumú kötetben több, mint 250 térkép és ábra, valamint 60 színes tábla segíti az események és összefüggések megvilágítását. Kapható a kiadó weboldalán (dialogcampus.hu) 20\%-os kedvezménnyel.
(Dr. Hegedüs Ernő mk. alezredes) 